Article

\title{
Will Naomi's Nation be Ruth's Nation?: Ethnic Translation as a Metaphor for Ruth's Assimilation within Judah
}

\author{
Katherine E. Southwood
}

Department of Theology, University of Oxford, Oxford OX1 3LD, UK;

E-Mail: Katherine.southwood@theology.ox.ac.uk; Tel.: +44-1865-277394

Received: 13 February 2014; in revised form: 2 April 2014 / Accepted: 3 April 2014 /

Published: 9 April 2014

\begin{abstract}
This article utilizes research concerning assimilation as a heuristic analytical tool through which to understand some of the factors that may have influenced Ruth's and Naomi's assimilation (or re-assimilation in Naomi's case, having returned to Judah) within the Biblical book of Ruth. Initially, analysis of research concerning assimilation, research which originally emerged within the U.S. but has since developed on a larger and more sophisticated scale, is undertaken before the article turns to evaluate the narrative within the book of Ruth in light of the literature from social and cultural anthropology. Such literature considers the impact that family, friendship, and religious networks have on immigration and assimilation. It is suggested that the concept of "ethnic translation" rather than assimilation is more appropriate to the experience represented within the narrative. Furthermore, it is argued that Ruth's assimilation, or ethnic translation and Naomi's return migration and re-assimilation (or ethnic re-translation) are assisted greatly by family networks and by religious participation. While primarily a study of Hebrew Bible narrative, the interdisciplinary nature of the article enables it to serve as a springboard for larger reflections, especially in light of the new concept of ethnic translation.
\end{abstract}

Keywords: Ruth; Naomi; Hebrew Bible; Old Testament; migration; assimilation; ethnicity; translation

\section{Introduction}

With its barley harvests and its rural setting, the "great short story" of Ruth has been described as "among the best and most charming stories in The Old Testament" ([1], p. 53; [2], p. 257). However, one needs little more than a cursory glance through the material to recognize the tensions arising as a 
result of ethnicity within the narrative. This is only too evident through the language selected by scholars in describing and evaluating the text. Matthews remarks "intrinsic to this story is its multi-cultural nature. Two ethnic groups, Moabite and Israelite, are involved” ([3], p. 51). Likewise, Lau comments that "from the outset ... an implied reader would have viewed Ruth with suspicion; she would have been stereotyped as a member of an outgroup" [4]. One of the most prominent tensions arises through the matter of Ruth's assimilation having migrated, and Naomi's re-assimilation having return-migrated. Unsurprisingly, therefore, as will be discussed, terms such as "assimilation" and "integration" are frequently found during discussions about the book of Ruth. While such terminology is appropriate to the narrative within the book of Ruth, it is nevertheless useful to concretize our understanding of what exactly is being referred to when we use such terms drawn from sociology and anthropology. As such the initial section of this article addresses the issue of assimilation and two factors which influence assimilation, namely, religious networks and family networks [5].This research will subsequently be utilized as a prism through which to understand and analyse the narrative concerning Naomi's return migration with Ruth to Judah.

\section{Early Approaches to Assimilation}

Initially, it should be noted that debates often emerge concerning various ways of defining and distinguishing assimilation from similar terms within the semantic field. For example, some sociologists such as Bruce and Yearley distinguish integration and assimilation, claiming that assimilation falls somewhere between accommodation and acculturation. Accommodation describes relations between discrete populations where co-existence emerges without the loss of defining characteristics. In contrast, acculturation is the process in which a minority is absorbed into the majority and entirely loses its distinctiveness. However, integration refers to the extent to which individuals experience a sense of belonging to a collectivity by virtue of "sharing its norms, beliefs and values" ([6], pp. 2, 154). The reasons lying behind such distinctions between various terms relate to early, ethnocentric, use of the term assimilation.

The paradigmatic research on assimilation emerges from the Chicago School of Sociology and especially to the work of Park, and Thomas [7,8] Sometimes referred to as straight line assimilation, the theory was that with each successive immigrant generation, ties to the old country are weakened while ties to the receiving country are strengthened until ethnicities are blended in a melting pot of WASP (White Anglo-Saxon Protestant ) identities [9]. However, as Glazer and Moynihan illustrate, the point about the melting pot is that it did not happen [10]. Later theories involved creating a typology of assimilation. The first and easiest stage was to achieve cultural assimilation (or acculturation) and involved picking up the language, social mores, and outlook of the mainstream society [11]. Yet, since the 1960s, with increasing multiculturalism, is has been considered ethnocentric to expect immigrants to discard all of their traditional values as inferior to WASP identities [12]. Such expectations may mirror differences between emic and etic assumptions about assimilation. While emic (the perspective of locals who are being observed by fieldwork researchers) perspectives may expect minorities to merge with majorities, etic (the perspective of the scientifically orientated ethnographer) perspectives may recognize the ethnocentricity within such expectations. 


\section{Segmented Assimilation Theory, Ethnic Change and Complex Boundaries}

Despite this insistence of some to cling to old ideas about assimilation, many modern scholars have attempted to refashion the concept of assimilation [13]. One approach to the topic which has gained popularity is that of segmented assimilation theory, a theory first formulated by Portes and Zhou who argue that a critical question concerns the segment of a society into which individuals assimilate [14]. According to this theory, various assimilation outcomes are possible but they depend on the interplay of individual and structural factors alongside immigrant cultural traits and social capital. Effectively, a matrix of social factors determines which adaptation path an immigrant follows.

Box 1. Three possibilities for immigrants which are outlined within segmented assimilation theory [15].

1. Standard acculturation where immigrants acculturate into the middle-class mainstream.

2. Downward assimilation where immigrants come up against impassable social and economic barriers that lead to permanent poverty while, at the same time, assimilating with native, inner-city underclass population.

3. Nonassimilation, where immigrants remain separate from mainstream society (either intentionally or as a consequence of discrimination) but simultaneously enjoy rapid economic advancement as a result of strong co-ethnic solidarity and support.

This model tightly connects assimilation with class and economic prosperity. While such a connection is important the model is reductive to the extent that other significant factors for assimilation such as the reliability and social capital of existing connections and relatives within the new environment appear to be less of a priority. However, this analysis of the model also reminds us of the problems faced by sociologists in defining and quantifying assimilation.

Perhaps a more successful attempt to describe assimilation is provided by Alba and Nee who start from the recognition of assimilation as a form of ethnic change (or, as will be argued, more appropriate to the experiences of Ruth and Naomi as depicted within the narrative, ethnic translation). Thus, Alba and Nee define assimilation as the decline of an ethnic distinction and its corollary cultural and social differences. In other words, as ethnic boundaries are weakened, individuals' ethnic origins become less and less relevant in relation to the members of another ethnic group and the individuals from both sides of the boundary mutually perceive themselves with increasingly less frequency in terms of ethnic categories and only under specific circumstances. Furthermore, Alba and Nee argue that assimilation is not a dichotomous outcome and does not require the disappearance of ethnicity; consequently, the individuals and groups undergoing assimilation may still bear a number of ethnic markers [16]. Alba and Nee's definition of assimilation completely avoids any charges of ethnocentrism. Part of the way this is achieved is through emphasizing ethnic change (or translation). Clearly, like many social anthropologists, Alba and Nee have an instrumental, as opposed to primordial, view of ethnicity [17]. Thus, ethnic change is possible not through losing one's ethnic identity, but through a new context where boundaries become less significant.

Terms such as boundaries, when used within discussions concerning ethnic assimilation, are reminiscent of the work of Barth [18]. However, rather than immediately connecting ethnic groups and 
boundaries in a Barthian style, a more helpful typology for this context which concerns boundary-related changes is that of Zolberg and Woon who categorize the changes in boundaries as:

- Boundary crossing. This corresponds to the classic version of individual-level assimilation: someone moves from one group to another, without any real change to the boundary itself.

- Boundary blurring. This implies that the social profile of a boundary has become less distinct: the clarity of the social distinction involved has become clouded, and individuals' location with respect to the boundary may appear indeterminate.

- Boundary shifting. This involves the relocation of a boundary so that populations once situated on one side are now included on the other: former outsiders are thereby transformed into insiders [19].

Zolberg and Woon's typology is extremely helpful to any discussion of assimilation, especially for return-migration and assimilation. Instead of reverting to the type of polarizing thinking which simplistically envisages migrant groups who stand outside a certain boundary and host communities within the boundary, the typology acknowledges the complexity of any given boundary and the importance of context [20]. While in some circumstances a boundary may appear insurmountable, in other situations or at a different point in time the same boundary may have been reconfigured somewhat differently, and perhaps even unrecognizable in relation to the former qualities of said boundary.

\section{Assimilation and Religious Identity}

One major factor which influences the properties of boundaries and the effectiveness of assimilation is religion. The connections between religious identity and practice, and assimilation have long-since been acknowledged. Early research on the topic argued that religion was an ethnically closed activity for immigrants and therefore it acted as an impediment to assimilation [21]. In contrast to the conclusions drawn from such early research, modern scholars present a variety of outcomes for assimilation, positive and negative, which may arise as a consequence of religion. Unlike the macroscopic conclusions of initial research, modern scholarship uses a more atomized approach with studies expanding not only the links between religion and assimilation [22-25], but also between religion and the formation of ethnic identities [26-28], and between religion, positive acculturation, and upward mobility [29].

The complexity of the connection is particularly explicit in light of Foner's and Alba's study which shows two potential roles that religious participation has for immigrants. Initially, it may be understood as a bridge which connects them to the community, provides information concerning jobs, housing and so on. Alternatively, it can also serve as a buffer against integration, as early research concluded, through restricting exposure to co-ethnics [30]. Akresh also points out the complications when attempting to survey the connections between assimilation and religious identity and participation. In the context of immigrants to the U.S., Akresh argues that "there is a tendency towards greater religious attendance with increased time in the U.S." ([31], p. 657). However, Akresh also points out the importance of taking into account past, or pre-immigration, religious practices and the effect that residence can have on participation; "residence in an ethnically concentrated neighbourhood is likely to be associated with...an individual's religious participation" ([31], p. 658). 
Despite the difficulty of attempting to analyse the impacts of religious belief and practice upon assimilation, recent studies have drawn some useful conclusions about the nature of the connection. Feldman's examination of Islamic religious networks and their salience among the young, especially in relation to finding suitable marriage partners, is particularly interesting. Concerning diasporic communities with some religious affiliation, Feldman comments

Together, these population movements create collectivities in new sites that seek to produce new relations of community and belonging, which in their turn can provide the bases for emergent forms of kinship and identification ([32], p. 266).

One way in which religious participation provides "the bases for emergent forms of kinship and identification" relates to young marriageable women. Feldman argues that "religious communities and Muslim identification" provides a key resource for "individual identity" which builds on "adherence to particular religious practices" ([32], p. 268). The need for such religious affiliation among diasporic communities is highlighted by Feldman's study. Since assimilation can be slow and difficult, many immigrants experience alienation, especially in urban spaces. Nevertheless such urban environments also "generate conditions that promote the desire to build new forms of belonging and solidarity to replace the loss of proximate family and kin" ([32], p. 268). In the new conditions, many immigrants "seek to find and create understandings and meanings through their identification with religious communities where faith provides a moral compass to guide marriage and family life" ([32], p. 272). Therefore, rather than having a negative impact on assimilation, as suggested by older research into the connection, Feldman's study highlights that displacement and uncertainty can also provide opportunities wherein people create new relations of social engagement, belonging, and acceptance. Nevertheless, one may also argue that Feldman's research can be seen as a restricted, or partial, form of assimilation. While assimilation is occurring, it is restricted to Islamic communities.

A number of recent studies have also highlighted the significance of the positive impact that religious institutions potentially have on assimilation. Rather than acting as something quite restrictive, religious institutions can actually play an important bridging role between immigrants and host societies [30,33-35]. Religious institutions can act as incubators of social capital [36] and, as such, can facilitate immigrants in diversifying and strengthening their social networks. As a consequence, immigrants participating in religious institutions may gain increased access to information about jobs and other important aspects of their local contexts and this, in turn, can assist the process of assimilation [37]. As Allen argues (for the U.S. context),

As one of the few familiar institutions that they experience when they arrive in the US, religious institutions can play a significant role in how refugees rebuild their social networks, maintain their cultural traditions and seek assistance ([38], p. 1051).

However, despite this general agreement among scholars regarding the bonding and bridging social capital and often positive role that religious participation has for assimilation, it is important to maintain an awareness of context. As Allen points out, not every place of worship functions in the same way; minority religious traditions sometimes provided only bonding social capital, thus reinforcing existing connections with immigrant communities while failing to provide the all-important bridging social capital which supports assimilation [38]. 


\section{Assimilation and Family Networks}

A second factor that has a marked influence on assimilation is the existence of family networks. Numerous studies demonstrate that transnational connections to the homeland, especially among first-generation immigrants, can remain strong over time in diverse migrant communities. However, such ties are weakened among successive generations [39-41]. Similar to the function that religious institutions play in assisting assimilation, family and friendship networks can have a role in binding communities together. Familial social networks provide the basis for social cohesion, solidarity and civic participation since family networks also create bonding social capital [42-44]. Furthermore, family bonds can be utilized as a social resource in the construction and maintenance of ethnic identity [45-47]. As such, family networks in the host society may hinder assimilation as a result of the absence of bridging social capital [48-50].

Perhaps one of the most intriguing aspects about the impact of family networks on assimilation is the markedly different effects that they have for return migrants (in contrast with immigrants). For example, a recent study by Reynolds demonstrated how transnational family ties and social networks are utilized as social capital resources to facilitate young second generation return migrants from Britain to the Caribbean, their parents' country of origin [45-47]. Of course, return migration is a complex process and can often result in the undoing of idealized notions of the homeland and alienation [51-58]. One particular problem for many migrants and return-migrants is language, and the returnees within Reynolds study experienced a sense of being "outsiders" as a result of their accents ([59], p. 807; [60]). This sense of being an outsider was particularly pronounced among young female return migrants who

...expressed concerns about how to conform to gender-related cultural expectations and practices in their everyday daily lives. A number of the female participants remarked that, outside of family contexts ... it was very difficult to socialize with other women in public spaces ([59], p. 808).

Thus, while in general return migrants experienced difficulty in adjusting and assimilating those with the support of family networks found that inside the family context there was some degree of security and familiarity.

This conclusion is also reached by Tiemoko who argues that families play an important role in return migration, remittances, and aspects of human, social and financial capital acquisition and investment [61]. Focusing on the issue of return migration and assimilation of return migrants to Côte d'Ivoire and Ghana, Tiemoko illustrates the powerful role that families and family networks play in influencing decisions to return migrate. The findings from the study lead Tiemoko to argue that with regards to the time spent abroad, "family-influenced migrants stayed abroad longer than non-family-influenced migrants in both the elite and the less-skilled groups" since families have an important role to play in relation to the development, transfer and use of certain forms of capital ([61], p. 6). Alongside social capital, families also played an important practical role, having "a positive influence on the volume of remittances, the transfer of savings and the nature of investments by migrants" ([61], p. 10). Furthermore, Tiemoko highlights the provision of information another important role played by families, arguing that 
International migrants seek up to date and reliable information on their country of origin, both to plan their return, as well as to feel satisfied in their lives abroad. The West African data used here shows that social networks in the country of origin remain the main source of information, especially information concerning security and job or investment opportunities ([61], p. 10).

A similar point is made by Reynolds who argues that return migrants used family networks in order to ...assist them with practical details of return such as the building and purchasing of homes, finding work and other employment opportunities, and information concerning duty and tax concessions. The contacts that emerged through family bonds were especially crucial to the second generation returnees finding work because securing suitable employment heavily depends on existing contacts and reciprocal trust relationships ([62], p. 17).

A range of studies concerning the role that family networks have on return migrants reach similar conclusions. One particular theme which exists amongst the research is that strong family ties and connections to the homeland provide the primary reason for return over and above economic, social, and political considerations [57,63,64]. Effectively, therefore, as Potter notes, "return migrants are best viewed as people endowed with social capital, [and] potential" ([65], p. 14). Indeed, it has been suggested that family narratives actually promote the "myth of return" [66] and nurture a culture of diasporic identities while away from the homeland ([62], p. 14). Effectively, while family networks often act as an impediment for migrants, for return migrants' family networks within the place of origin play a vital role in assisting assimilation. Not only do they provide social capital, they also often provide practical assistance.

\section{Ethnic Translation within Ruth: Terminology and Definitions}

Having briefly examined some aspects of the material concerning assimilation, we now turn to evaluate the extent to which this research is helpful for gaining a more refined understanding of assimilation (or, as will be argued, ethnic translation) within the book of Ruth. As mentioned, terms such as assimilation and integration regularly appear in the work of numerous biblical scholars during discussions about the book of Ruth ([3], p. 53; [67-69]). Indeed, in his commentary, Matthews refers to the arrangement between Ruth and Naomi as a contractual one, or an "assimilation ritual that transforms Ruth from a Moabite to a member" [70]. Furthermore, in a later article, Matthews claims that the "community as a whole comes to recognize the value of allowing assimilation of foreigners" ([3], p. 55). Similarly, Oznik argues that Ruth is a model immigrant; thus the book is a tale of reinvigoration through conversion [71] and assimilation [69]. In contrast, Brenner argues that as a "low-class foreign woman" and a "worker without property", Ruth prospects are "less than promising". Therefore, instead of using the term assimilation, Brenner claims that Ruth will "be absorbed rather than integrated" since as a result of her low socio-economic status, "full integration, even in the case of Ruth, an exemplary female character ... is in fact impossible” ([72], pp. 161-62). Similarly, Honig does not so readily see assimilation occurring within the narrative, arguing that Ruth's closing silence leaves open the question "Has she been successfully assimilated, or has she been left stranded?" ([1], p. 53). As such, "Ruth's incorporation into the Israelite order is ... ambivalent"; rather than providing a picture of 
assimilation, "the text of the book of Ruth suggests complication, recalcitrant particularism and prejudice" ([1], p. 60). Effectively, therefore, while some argue that the book of Ruth presents its main protagonist as a model of assimilation, others claim that Ruth is never fully assimilated, or incorporated, but at best, absorbed.

One significant difficulty when addressing the question of assimilation within the book of Ruth is the variety of terminology which is instinctively applied without clear definition. It is assumed that readers will have a vague or intuitive understanding of the concepts at stake and will be able to distinguish one term from another. Is Ruth absorbed, integrated, assimilated, or none of these? Perhaps overstating the problem may highlight its significance: does Ruth permeate into, percolate through, or diffuse across Judean society? Furthermore, how should we describe what Naomi does without confusion, given that Naomi is a return-migrant? Perhaps the most logical way of bringing some clarity into the debate is to utilize the language and definitions which are readily available through consulting sociological research as a springboard. As discussed, Bruce and Yearley's definition of assimilation stated that assimilation fell somewhere between accommodation (co-existence without the loss of unique ethnic characteristics) and acculturation (co-existence with the loss of unique ethnic characteristics); and that integration refers to shared norms, beliefs and values and a sense of belonging [6].

These definitions can easily be applied to Ruth; however, it becomes clear very quickly that the situation within the narrative requires a more complex understanding of the terms than can be provided by dictionary definitions. The main complication is that Ruth is not just a migrant, but she is a migrant who is accompanied by a return-migrant. For example, Bruce and Yearley's definitions might lead one to conclude that most of the way through the book Ruth is accommodated, but not acculturated as a result of the author's persistent use of the epithet "Ruth the Moabite" [73]. Likewise, using Bruce and Yearley's definitions alone one could argue that at the beginning of the narrative Ruth makes the decision to integrate prior to migrating as a result of some degree of pre-existing knowledge of Judean ethnic identity which she gains from participating in a family of Bethelemites, some of whom have intermarried with Moabites such as herself (Ruth 1:1). Ruth intends to serve Naomi's God, and to integrate her people (Ruth 1:16-17). As will be discussed, the added complication of Naomi, a return

migrant, accompanying Ruth means that the question of Ruth's assimilation is left open if we consult dictionary definitions of assimilation alone. Clearly, if one is to apply theories and terminology from sociology and anthropology concerning assimilation to Ruth, a broader understanding of assimilation within the context of debates within the field must initially be applied.

\section{Ruth “The Moabite”}

One obvious advantage of utilizing the wealth of material concerning assimilation which is available, as opposed to dictionary definitions, is that a broader understanding of the most pertinent matters at stake is gained. As we observed, one such matter which was highlighted through the progression of the debates was an increasing self-awareness, among those participating in fieldwork research and writing up results, of ethnocentric biases. Why should those migrating to America embrace WASP identities and have their own ethnic background wiped out through "melting" into the American mainstream? 
When the same questions are considered for evaluating assimilation within Ruth, an unusual set of concerns arise. Matthews comments:

Although Ruth's stated goal is assimilation with Israelite culture as it is manifested in Bethlehem, acculturation processes are not one-sided. The community in Bethlehem will have some choices in their response to Ruth's presence.... ([3], p. 53).

Despite the article's overall merits, at this point in the argument it seems that the terminology adopted by Matthews is all too reminiscent of older models of assimilation theory where the initial stage of assimilation is acculturation [11] and this is followed later by assimilation. An assumption, implicit within such early theories, was that those assimilating to [74] host societies had inferior ethnic identities, and as such inferior values, dress, language, customs, and so on. An understanding of how debates concerning assimilation have changed since early theories casts an interesting light on the assumptions, or lack thereof, within the book of Ruth, but also those assumptions reflected in the writings of scholars who discuss assimilation in Ruth. Despite the repetitions of the epithet "the Moabite" almost every time Ruth's name is mentioned, the connotations of this epithet within the narrative itself are never fully explained.

Of course, if we consult other material within the Hebrew Bible concerning Moabites, one would assume that the epithet functions as a badge of disgrace for Ruth [75-77]. This context cannot be ignored and, as discussed, it may be understood as an emic approach to assimilation. However, with knowledge of assimilation theory and its progress, a more etic approach to the narrative would be to set aside the association between outsider ethnic identities, such as Moabite, with inferiority to Judean ethnic identities. One way of achieving this is to ignore the baggage associated with the ethnic label "Moabite" outside of the narrative, for now, and to examine its function within Ruth.

It may be argued that in the narrative alone, the epithet is neither positive nor negative, but simply acts as a descriptor. As Matthews comments, "no trace of what a Moabite believes or considers essential is mentioned in the text" ([3], p. 51). Indeed, all the information we are given is that Moab is a place of sojourn during a famine in the homeland, "a man from Bethlehem, Judah went to sojourn in the land of Moab, he his wife, and his two sons" (Ruth 1:1; cf. Gen 12:10). The displaced family do not restrict themselves to ethnically endogamous marriages but intermarry with Moabite וישאו להם נישים women, a detail given without negative or positive connotations, "and they took Moabite wives" (Ruth 1:4) [78]. Although not a match for Ruth's loyalty, the Moabite women display some loyalty towards their mother-in-law, Naomi (Ruth 1:10). With this context informing Ruth's Moabite ethnic identification, the label does not necessarily have to be interpreted as pejorative. It is merely an indicator that Ruth is not a Judean. However, as will be demonstrated, it does not necessarily follow that the retention of the label is evidence of Ruth's failure to assimilate. Nevertheless, this raises a worrying question concerning the assumptions of scholars who comment about Ruth's assimilation or lack of assimilation. Is there also an ethnocentric bias among scholars who read Ruth? Why are biblical scholars so keen that Ruth should lose all traces of Moabite identity in order to become a Yahwist and to assimilate with Naomi's people? There is a danger that such attitudes mirror older "borg-like" [79] notions of assimilation where resistance to melt one's own unique ethnic identity is futile. 


\section{Ruth “The Moabite”: Ethnic Translation Rather Than Ethnic Transformation}

As we have seen, a model of assimilation which is more broadly accepted within sociology and anthropology is that of segmented assimilation theory where distinctions are made between standard acculturation, downward assimilation, and nonassimilation. This model exposes numerous considerations which may have been overlooked by scholars writing about Ruth's assimilation. For example, Brenner argues that "integration in the host community can only be achieved by marriage" and that whereas "cultural, religious, linguistic, ethnic and similar variables can be overridden" ultimately "the factor of class, of social background and wealth ... is the decisive determinant". Therefore, for Brenner, Ruth is "a prime example of this reality: a low-class foreign woman, a worker without property, [who] will become invisible in the host community" ([72], pp. 160-61). As a consequence, "full integration even in the case of Ruth, an exemplary female character in many ways, is in fact, impossible" ([72], p. 162). One problem with this argument is the assumption that hypergamy, or the marrying "up" into a high social class, is not a possibility for foreign workers [80-82]. If Ruth is understood as a lower class foreign immigrant, then surely her marriage is an excellent example of hypergamy? A larger problem is the suggestion that assimilation is only possible for lower class female workers through marriage. Despite these difficulties, this argument could only have benefitted from an awareness of segmented assimilation theory. From this perspective, the picture that Brenner paints of Ruth is that of downward assimilation. In this case, Ruth does not assimilate as a consequence of impassable social and economic barriers. Were it not for the marriage with Boaz, Ruth would not have achieved standard assimilation. Since we are not informed of any other Moabites in Judah, nonassimilation would be deemed by segmented assimilation theories to be impossible.

Despite the popularity of segmented assimilation theory, like any model which attempts to quantify assimilation, it nevertheless has various flaws, particularly its reductive focus on socioeconomic status. As discussed, a different, more persuasive, attempt to describe assimilation is provided by Alba and Nee whose analysis of assimilation begins with the argument that assimilation is a form of ethnic change where ethnic distinctions, despite continuing to exist, become irrelevant and the use of ethnic categories decreases [16]. A particular strength of this model is that it acknowledges the fluidity, and socially constructed nature of ethnicity itself. Ethnicity is notoriously difficult to define and, as such, broad approaches to the topic are categorized ([51], pp. 19-71). Therefore, rather than beginning with the question "to what extent can Ruth change her ethnicity?", approaching narrative within Ruth from the perspective of Alba and Nee's theory places ethnicity, alongside a wide variety of other factors which can influence the success, of lack thereof, of migrants' and indeed of Ruth's, assimilation [83]. Given Alba and Nee's model of assimilation, what light can be shed on the narrative? In order to answer this question, ethnic categories must be explored initially.

As mentioned above, the most obvious marker of otherness in the book of Ruth is the repetition of the epithet "the Moabite" throughout the narrative. We are never allowed to forget the fact that, as Jackson phrases it, "Ruth, she is a Moabite, you know, one who comes from Moab, which is incidentally where all those Moabites originate" ([84], p. 194). The extent of the repetition is indeed somewhat absurd in places; Ruth is "the Moabite ... who returned from the country of Moab" (Ruth 1:22). Nevertheless, readers are left in no doubt about the centrality of Ruth's ethnic identity to the narrative. As such, Glover argues that Ruth's ethnic transformation mysteriously occurs at the end of 
the text when it "abandons its obsession with Ruth's ethnicity" ([85], p. 294). Effectively, for Glover, the Moabite tag is used whenever Ruth's situation within Israel is recognized. Therefore it is abandoned "first, in the eyes of Boaz, then Naomi, and finally the entire assembly of the people" ([85], p. 302). Glover argues that this transformation is achieved through Ruth's countering Moabite stereotypes with acts of goodness.

In sharp contrast with Glover, numerous scholars argue that Ruth never really assimilates. Yee insists that despite Ruth losing the qualifier "the Moabite" in 4:13, she is not really recognized as Obed's mother since "Naomi's ultimate incorporation back into the community is manifested by her displacement of Ruth as Obed's mother" and this revitalization of the community "depends not only on Ruth's exemplary character but also on her marginalization as a foreigner" ([76], p. 130). Therefore, despite being "the model emigrée", for Yee Ruth nevertheless remains "the perpetual foreigner" ([76], p. 120). In this case the only reason that Ruth is a hero is for propagandistic purposes, to emphasize the importance of to Israelites, thus her virtue is in spite of her foreignness. Similarly, Honig interprets the repetition of the Moabite epithet as evidence that Ruth "in some sense stays a Moabite, forbidden, surely noticed and perhaps despised by her adopted culture even while also celebrated by it" ([1], p. 60). Given this division of opinion it is necessary to return to examine the text itself in light of Alba and Nee's model.

\section{Ruth “The Moabite”: A Foreigner who is Recognised}

The name "Ruth" occurs twelve times in the book (Ruth 1:4, 14, 16, 22; 2:2, 8, 21, 22; 3:9; 4:5, 10, 13). Of these times, the name appears without the appellation while Ruth is in Moab (Ruth 1:4, 14, 16), during discussion with Boaz regarding gleaning (Ruth 2:8), in a private discussion with Naomi (Ruth 2:22), in a private discussion with Boaz (Ruth 3:9), and upon her marriage to Boaz (Ruth 4:13). Therefore, at points in the story, the epithet is used and at other points including the final mention, it is not. The points where the appellation is not used have, as discussed, given rise to much speculation, however perhaps too much weight is placed on its absence in the last mention of Ruth. This is not necessarily an indication of Ruth's complete assimilation. Indeed, as noted, according to Alba and Nee's model of assimilation, one does not have to entirely loose one's ethnic identity for assimilation to occur; instead it is simply less relevant. A good analogy is to use the term "translation". Words may be translated into local languages, understood and accepted. However, translation does not necessarily need to replace the original. Similarly, Ruth's ethnicity may be translated for the purposes of assimilation but this does not mean the original fades away.

This perspective correlates well with the lack of the epithet during the discussion between Ruth and Naomi. Naomi's primary relationship to Ruth is not of an Israelite with a Moabite, but as a mother-in-law with a daughter-in-law. As such, one could argue that as a result of the family tie, Ruth's ethnicity is less of a concern. This argument is also reinforced by the fact that Naomi has personally spent time amongst Moabites - apparently peacefully with intermarriages occurring - during the famine in her own homeland; such exposure may also have weakened Naomi's sense of ethnic difference between herself and her daughter-in-law. Effectively, for Naomi, Ruth's Moabite origin is not relevant, thus it appears the author has carefully excluded the epithet from the dialogue. 
The lack of appellation at the beginning of the narrative is also understandable. While Ruth is in Moab there is no reason to designate her as a Moabite. It is also important to note that throughout the narrative, the appellation never occurs alone; Ruth is always Ruth the Moabite, never just "the Moabite". As such, although Ruth's ethnic difference is noted, she is not seen as an anonymous, unknown foreigner in the way that foreign women are understood in other texts, such as Ezra-Nehemiah, or Proverbs. Rather, Ruth is acknowledged and recognized as Ruth alongside being acknowledged as a Moabite. In light of Alba and Nee's model, where assimilation is "does not require the disappearance if ethnicity", or of the analogy of ethnic translation, one may argue that throughout the narrative the recognition of and personal designation of Ruth is already a form of assimilation [16].

One particularly interesting aspect of the narrative is the lack of the Moabite descriptor during Ruth's first encounter with Boaz. The second of these encounters is unsurprising since it occurs with Ruth's marriage to Boaz; intermarriage has long been acknowledged as one of the primary markers of assimilation ([11]; [51], pp. 62-71.) Why, therefore, does the author choose to drop the appellation during Boaz's initial encounter with Ruth? When Boaz initially notices Ruth she is, according to the reapers, "the Moabite ... from Moab" (Ruth 2:6). Yet, during their conversation, Boaz and Ruth are set alongside one another without further descriptors (Ruth 2:8). Indeed, it is Ruth who insists on the ethnic label foreigner' נכר (Ruth 2:10).

Ruth's choice of this word is interesting. A range of terms exist to describe foreigners within the Hebrew Bible: The term "stranger" זר which can mean a member of another household or tribe but can also describe a foreigner; a "foreigner" נכר, and a "sojourner" גר זר. A couple of other less common terms appear to describe foreigners; a "settler" תושב (Ex. 12:45), and "another" אחר (Judg 11:2). Within the book of Ruth, we are immediately informed that Elimelech and his family travel from Bethlehem, Judah "to sojourn" גור in Moab (Ruth 1:1). As such, in Moab they are foreigners who have been forced to migrate to a place wherein they have no familial or tribal affiliations [86]. However as Matthews notes, "curiously" the term גis "not used here for Ruth" ([3], p. 54). This is indeed, rather strange since the text does, as Yee argues, imply that Ruth is a sojourner in her action of gleaning and, as such, it is implied that she is taking advantage of the laws for the poor, the sojourner, and the widow (Lev. 19:9-10; 23:22; Deut. 24:19-22) ([76], p. 127). Nonetheless, the stronger term "foreign woman" is instead used as self-identification on the lips of Ruth:

Why have I found grace in your eyes, that you should recognize me להכירני, a foreign woman נכריה ? (Ruth 2:10) [87].

Those designated as foreigners do not usually receive the legal protection that the sojourner receives (Deut. 23:20; Judg. 19:12) [88]. Furthermore, the descriptor "foreign woman" is used to underline ethnic differences during the intermarriage narratives within other post-exilic texts such as Ezra and Nehemiah (Ezra 10:2, 10-11, 14, 17-18, 44; Neh. 13:26-27) [89]. Effectively, Ruth's selection of the term "foreign woman" in her answer to Boaz firmly sets her at an ethnic distance.

However, as formerly noted, Ruth is far from anonymous. Instead she is "recognized", particularly by Boaz. The pun on נכר not only highlights the well-crafted nature of the narrative, it also illustrates this argument concerning Ruth's recognition regardless of her ethnic identity effectively. In the same sentence the homonyms נכר ("Recognize" "Foreign") appear and are used as antonyms. Boaz is the linchpin to Ruth's assimilation through eventual intermarriage, but initially through his recognition of 
her; the polar opposite to seeing only a foreigner. The term is used, usually in hiphil, of identifying a person or object which is known (Gen. 27:23; 37:33; 38:26), of acknowledgement (Deut. 21:17; 33:9; Dan. 11:39). However, it is also used in the sense of a realization of a person's true identity and status [90].

...he recognized him... that he was one of the prophets (1 Kings 20:41).

...they will acknowledge them that they are the offspring that Yahweh has blessed (Isaiah 61:9).

...he shall acknowledge the firstborn by giving him a double portion (Deuteronomy 21:17).

The recognition does not equate to some sort of an ontological change; rather, a change in or different perception and interpretation of the person or group at stake is signified, that is ethnic translation. As such, Boaz's recognition of Ruth and the narrator's lack of the epithet at this point should not lead us to conclude that Ruth is any less of a Moabite; rather, Ruth's Moabite ethnic identity is not relevant, and as such Ruth has entered what Alba and Nee describe as the "dichotomous" process of assimilation [16].

Despite Ruth's successful assimilation, it is not possible to conclude that as a consequence Moabites are more generally accepted or that the ethnic boundary has somehow changed. Although for Ruth boundary crossing appears to be possible, there is nothing in the text to suggest that Moabites more generally are accepted within Judah. As noted during the former discussion of ethnic boundaries, despite the prevalence of the Barthian approach, a more modern typology which acknowledges the complexity and fluidity of boundaries may be better suited to studies of assimilation. Thus, Zolberg and Woon's list of boundary-related changes including boundary "crossing", "blurring" where the boundary becomes less distinct, and "shifting" where the boundary is relocated and former outsider populations are now included, were important [19]. A number of scholars have noticed, along the same lines as Honig, that Ruth's assimilation within Judah occurs despite her Moabite ethnic identity; "Israel is open only to the Moabite who is exceptionally virtuous" ([1], pp. 55-56). Similarly, Yee comments that "Ruth is held up for propagandistic purposes ... she thus reveals what a virtuous foreigner can teach the nation" ([76], p. 129). It is precisely this irony upon which the story pivots; a non-Judean shows the way to the Judeans. As such, following Zolberg and Woon's typology, no changes can be traced in the existing ethnic boundary between the Moabites and the Judeans. Indeed, without such an inflexible boundary Ruth's story would no longer be surprising or exceptional. It is only in relation to Ruth, the individual not the group that the boundary changes and assimilation occurs. The change is, nonetheless, gradual throughout the narrative. Initially, the boundary is blurred through Ruth's familial relationship with Naomi. Secondly, following Ruth's determination to assimilate and her intermarriage with Boaz, the boundary shifts ever so slightly to include Ruth. In Ostriker's words, "Ruth crosses the border between the land of Moab and the land of Judah and is accepted" [91]. Honig expresses this change effectively, through contrasting Ruth the Moabite and Orpah the Moabite which highlights “the extraordinariness of Ruth's border crossing." Ruth's migration

...does not mean that Israel is now a borderless community open to all foreigners, including even idolatrous Moabites ([1], pp. 55-56). 
Effectively, therefore, Ruth's assimilation is a stark exception to the rule: Ruth is the solitary outsider for whom the boundary shifted. The reasons which are provided to explain Ruth's exceptional inclusion are usually attributed to Ruth's and to Boaz's overriding character trait of kindness חס [92]. However, one benefit of utilizing literature concerning assimilation to assess the narrative is that less obvious explanations arise.

\section{Ruth's Access to Religious Networks}

In light of the literature which has been considered formerly concerning assimilation, it is probable there are two primary reasons for Ruth's successful assimilation. Initially Ruth's commitment to Yahwism, which opens religious networks, plays an enabling role. Secondly, and perhaps more importantly, Ruth is not a foreigner who appears on the scene alone, rather she returns with Naomi, a Bethlehemite return migrant. As such, Ruth is not a complete outsider, but has access to local information and social networks. Without Naomi, Ruth may have ended up remaining outside the boundary, like one of the foreign women of Ezra 9-10 and Nehemiah 13. It is these two important factors in combination which result in Ruth's Moabite ethnic identity no longer mattering and her successful assimilation or ethnic translation.

As formerly discussed, one key factor which is likely to have an impact upon assimilation is past, pre-migration, religious practices [31]. We do not know what form of religious affiliation Ruth was practicing in Moab. However, we are informed that she was married into a Yahwistic family. It would not be unreasonable to surmise that Ruth would already have some exposure to Yahwism, albeit the type of Yahwism maintained by those who have been forced to migrate away from the homeland, or to put it another way, those in exile [93]. However, we know little more about the religious practices which occur since they are not discussed during the narrative. Nevertheless, as Ostriker observes, "between the opening and the close, God does not appear but is continually invoked" ([91], p. 45). "The Lord" functions almost as a salutation at times within the narrative. For example the greeting between the harvesters and Boaz consists of invoking "the Lord" to be with, and then to bless (Ruth 2:4). The Lord's blessing is also used as characters' reactions to good news (Ruth 1:8-9; 2:20; 3:10). Similarly, the Lord is invoked as a means of describing circumstances. For example, Naomi claims that "the Lord has afflicted me" and upon Obed's birth, the women "praise the Lord who has not left you [Naomi] without a kinsman redeemer" (Ruth $1: 21 ; 4: 14$ ). Finally, the Lord appears in oaths (Ruth $1: 17 ; 2: 12 ; 3: 13)$.

The evidence suggests that despite the lack of religious practice being mentioned within the narrative it is clear through dialogue and speech that Yahwism permeates everyday life and in the thoughts of characters. People's situations are portrayed as determined by the Lord who will punish those who do not keep their oaths, and wishing somebody well is the same as desiring that the Lord be with them. The Lord is on the lips on anonymous crowds, such as women and harvesters, and on the lips of the main characters, Naomi, and Boaz. What is interesting here is that the Lord also features within Ruth's speech (Ruth 1:17). As such, prior to migrating with Naomi to Judah Ruth already displays some knowledge of how religious affiliation operates in everyday life and she puts it into practice. Such conformity to Yahwism, which is ingrained in everyday speech and thinking, enables Ruth to talk and reason in similar ways to the existing population and as such may also have assisted 
her assimilation. Effectively, Ruth is able to translate successfully between her Moabite ethnic heritage and the new Judean identity which she embraces.

Another aspect of participation in religious networks is their impact on marriage. As discussed, new forms of belonging are sometimes found in religious networks and suitable marriage partners can be dictated by such networks [32]. Furthermore, we noted that religious institutions function as incubators of social capital which provides increased access to contextual information and assists the process of assimilation. As such, perhaps one of the most important aspects of Ruth's pledge to Naomi is the statement "your people will be my people and your God, my God" (Ruth 1:16) [94]. Sasson argues that this declaration "suggests not only the act of worshiping, but also alludes to all the deeds and acts which cement a bond between individuals and their deities" ([95], p. 29). Sasson's observation here highlights the potential impact of Ruth's pledge; it is not merely an individual decision, the entire religious community will be affected by Ruth's decision. A common approach to the statement is the recognition of covenantal language and loyalty here. Frymer-Kensky, who cites parallels from $1 \mathrm{Kgs}$

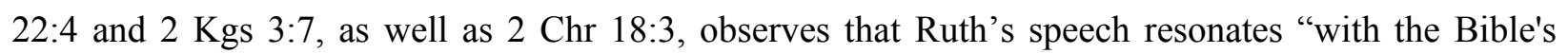
cadence of covenant and contract" ([96], p. 241). Similarly, Smith, comparing Ruth with Jehoshaphat states that "the words of Jehoshaphat represent the treaty / covenant relationship on the royal level across family lines; Ruth's words represent the covenant relationship across family lines' ([97], p. 255).

However, a more interesting comparison has been drawn by Matthews, and by Lacoque, who contrast Ruth's words and actions with those of Ittai the Gittite in 2 Sam 15:19-22. Like Naomi who implores Ruth and Orpah to return rather than accompanying her (Ruth 1:8-9) David orders Ittai the Gittite to "Go back ... for you are a foreigner נכרי and also an exile גלה from your home". Matthews suggests that

In both cases a choice is presented by a forced exile to those who have been loyal to seek security elsewhere in a safer context.... The implication is that the "foreigner" ... owes no obligation to Naomi or to David and maintains the connection with his native country ([3], p. 52).

Similarly, Ruth's actions can be compared to those of Ittai the Gittite if one argues that Ruth's pledge to Naomi in 1:16-17 is a form of voluntary displacement. The narrative's use of the verb "cling to" should also be recognised (Ruth 1:14). The verb can be used for more intimate relationships (Gen. 2:24; 34:3) ([2], p. 262), but the most appropriate comparison, given the context, is the loyalty expected between God and Israel as described in Deuteronomy: "You shall fear the Lord your God; you will serve him, and you will cling to דבק him" (Deut. 10:20). By remaining with Naomi, Ruth not only displays as Yahwistic type of covenantal loyalty, she also gains a useful amount of contextual information and social capital. If Ruth had not added "your God will be my God" to the statement "your people will be my people" assimilation would have been harder to achieve, and Naomi's nation may not have become Ruth's.

Another area where Ruth gains from access to a religious network is through Naomi's knowledge of local religious customs. Commandments concerning the protection of the poor and of sojourners may lie behind the narrative on an implicit level [98]. However, what is explicit is Naomi's insistence that Ruth exposes Boaz as kinsman in order that he can act as a גאל redeemer (Ruth 4). Despite the confusion surrounding what happened at the threshing floor [99], what is clear is that it is Naomi who 
initiates change for Ruth. The law of Levirate marriage is loosely applied here as a result of Naomi's pragmatic application of her own knowledge of religious custom [100]. As a result of Naomi's intervention, Ruth is able to remarry; one of the most prominent indicators of assimilation [101].

\section{Ruth's Access to Family Networks}

Perhaps one of the most important influences on the success or not of assimilation is the existence of family networks. As discussed earlier, family networks often play a significant role in influencing the decision to migrate but also in enabling successful assimilation. Interestingly, the decision to migrate is Ruth's despite Naomi's insistence that she return to her people and her gods (Ruth 1:15). Nevertheless, Ruth, a woman of expedition and action ([91], p. 43), indeed an אשת חיל (Ruth 3:11; Prov. 31), chooses to remain with her mother in law despite Naomi's resistance. This decision doesn't conform to the patterns set out in the discussion of literature concerning assimilation from social anthropology. As such, it is particularly interesting and underlines the uniqueness of Ruth's characterization. However, in order to analyse the impact of family networks on Ruth's assimilation, one must initially examine Naomi's path towards migration and assimilation. The fact that Naomi's migration is a return to her original homeland is emphasized at the beginning of Ruth through the twelvefold repetition of the verb שוב "return" (Ruth 1:6, 7, 8, 10, 11, 12, 15 (x2), 16, 21, 22 (x2)) [102]. Nevertheless, as formerly discussed, return is a complex process and can often result in return migrants feeling excluded and "outside of family contexts" finding it "very difficult to socialize with other women in public spaces" ([59], p. 808). Naomi's problematic adjustment to life in her homeland is clear in the initial chapter. Naomi is recognized immediately upon her return but immediately rejects her former identity, stating:

Do not call me "Naomi", call me "Mara": for the Almighty has dealt very bitterly with me. I went out full, and the LORD has brought me home again empty: why therefore call me "Naomi"? (Ruth $1: 20-21)$.

Various scholars have recognized this shift in Naomi's identity. Matthews argues that "as social exiles, when Ruth and Naomi leave Moab, they both experience a shift in their personal identity; it becomes fluid and indeterminate" ([3], p. 53). Indeed, Matthews highlights Naomi's liminality, claiming that she "can be seen as an "uprooted person," doubly so in fact since she has memories of her home in Bethlehem as well as the one she helped to create in Moab" ([3], p. 51). Similarly, Lau highlights Naomi's position as a "'member of an outgroup', and 'a childless widow and a marginalised repatriate' whose ties to her former clan and father's house are severed” ([4], pp. 124-25).

Naomi's change of personal name is particularly significant. Naomi's rhetoric not only betrays an expression of pain and frustration, it also symbolises how far her former identity is removed from her current experience. In response, Naomi's behaviour is typical of that of the return migrant; Naomi self isolates and seeks a new identity ([51], pp. 41-55). As a return migrant, Naomi's renaming herself may be seen as a "reflection of her inability ... to fully re-enter her previous discourse community" ([3], p. 53). This self-isolating behavior is expressed particularly well by Lau, who comments:

Her rejection of her former identity not only reflects her present feeling, it also serves to promulgate and entrench her in her situation. For in rejecting her former name, she is also 
alienating herself from her former community, the women who used to form her close social network. By demanding that they not call her Naomi any longer, she is effectively saying she is not the same woman they knew a decade ago. Hence they cannot relate to her as they used to ([4], p. 126).

As noted, family social networks usually facilitate quicker and more effective assimilation. However at this point in the narrative, far from attempting to integrate or assimilate, Naomi wilfully cuts herself off from her former community (and, as a consequence, also cuts Ruth's possibilities of assimilating). This is not surprising, given that Naomi is not simply a migrant who moves to a place within which a family network already exists. Rather, Naomi carries all the baggage of a return-migrant who realises upon return to the homeland that she is no longer belongs there [103]. Moreover, Naomi's family ties are mostly severed as a result of the loss of her husband and sons (Ruth 1:3). Nevertheless, unlike Ruth, Naomi is not in the position of a new migrant. Rather, Naomi is recognized, regardless of her embittered interpretation of her own circumstances. Furthermore, although Naomi returns to her homeland without family, she is nevertheless able to re-establish her family network through discovering Boaz, the kinsman and redeemer. It is clear from the beginning of the narrative in Judah that Naomi is aware of and intends to utilize this family tie (Ruth 2:1). As such, Naomi is actually in a position of advantage in terms of her re-assimilation. Naomi is not simply a foreign migrant, she is a return migrant who is recognized and who has the protection and assistance of family ties [104]. In light of the literature formerly discussed from social anthropology, this set of circumstances would heighten the possibility of assimilation for Naomi.

We noted previously numerous ways in which the existence of family networks can result in positive impacts on assimilation for return migrants. Family influenced migrants "stayed abroad longer" since family networks assist in the development, transfer and use of certain forms of social capital ([61], p. 14). Various studies also illustrated how families assisted assimilation through providing practical help, providing aid in acquiring job opportunities, and helping migrants seek reliable and up to date information $[57,61,63,64]$. The centrality of family networks in the book of Ruth is undeniable through the repeated use of family terminology. We are constantly reminded that the relationship between Noami and Boaz is familial through the repetition of the term "kinsman/redeemer" (Ruth 2:1 [105]; 3ודע 3:9, 12, 13; 4:1, 3, 6, 8, 14). Similarly, the familial bond between Ruth in relation to Naomi is emphasized through the repeated description of their relationship as "in-laws" (Ruth 1:6, 7, 8, 14, 15, 22; 2:11, 18, 19, 20, 22, 23; 3:1, 6, 16, 17; 4:15). Furthermore, Naomi sometimes refers to Ruth as simply "my daughter" (Ruth 2:2, 8, 22; 3:1, 10, 11, 16, 18). As Glover comments, "Ruth is a text which is dense with household relationships... it is these constantly repeated, nonbiological relationships which hold the book together" ([85], p. 305). Similarly, Matthews observes that

the family-based values and relationships ...[form] the cement that provides each its singular identity amidst a larger society comprised of crisscrossing social differences ([3], p. 51).

The family connection between Ruth and Noami is important and it can be argued that this tie is pivotal for Ruth's assimilation. Unlike the foreign women of Ezra-Nehemiah, Ruth returns with Naomi who, despite complications resulting from her status as a return migrant, nevertheless, retains a degree of social capital. As a result of Naomi's connection to Boaz, Ruth can find work which will sustain 
them (Ruth 2:2). Given the importance of Naomi's family network for Ruth's assimilation it is difficult to maintain that "the Judean ethnic identity of Naomi's family ... plays no role in the drama that unfolds" ([97], p. 257). At the beginning of the narrative as a total foreigner Ruth goes unnoticed, as Brenner states "the only one to notice Ruth at the end of ch. $1 \ldots$ is the narrator. Neither Naomi nor the Bethlehem women acknowledge her existence" ([72], p. 160). Ruth, like Abraham, had left her father, mother, and homeland to live with a people she did not know (Ruth 2:11; Gen. 12:1) [106]. However, unlike Abraham, Ruth is not a temporary sojourner, a גרen. 15:13; 23:4). Instead Ruth is a foreign woman נכריה who migrates to the land with a family network, remains there more permanently, and assimilates (Ruth 2:10).

\section{Intermarriage between Ruth and Boaz and Ethnic translation}

The pivotal figure for Ruth's assimilation, and to some extent, for Naomi's re-assimilation, is Boaz. Without Boaz, Naomi would not have any established family network and, as has been demonstrated, without Naomi's family network, Ruth would stand little chance of such a successful assimilation. Many scholars acknowledge the centrality of Ruth's intermarriage with Boaz for her assimilation and, as formerly discussed, one of the key measures of successful assimilation is intermarriage ([11]; [51], pp. 62-71). As Lau argues,

[Ruth's] identity as Boaz's wife means she is publically and concretely bound to the wider Israelite society $(4: 10,13) \ldots$. The consummation of their marriage and the birth of a son also signals the culmination of Ruth's aggregation into Israelite society ([4], p. 100).

We noted how family networks help migrants in various practical ways, for example, to acquire more exact information. In light of this, it is interesting that Naomi does not realise that Boaz is not the closest kinsman who may act as a redeemer. It is Boaz who, having been surprised by Ruth at midnight, points out that there is actually a closer, therefore more suitable, גאל than himself (Ruth 3:12-13). As a local, Boaz has more accurate information and is able to apply it in order to assist נכר Naomi and Ruth by acting himself as a redeemer, perhaps as a result of having truly recognised Ruth (Ruth 4:1-6; cf. Ruth 2:10).

In contrast to Lau, some question whether Ruth's assimilation is concretized by the intermarriage with Boaz and the birth of Obed and is anything more than partial. Brenner wonders if "foreignness (Moabite in this case) and class (worker) can be overcome, even when the foreigner conforms to a positive stereotype and embraces the local culture?" ([72], p. 160). Honig, who makes a similar point, is more forceful, arguing that

the book of Ruth makes a point of the fact that Naomi takes Obed from Ruth to nurse. ... [signalling] the community's continuing fear of Ruth's foreignness. Ruth the Moabite cannot be trusted to raise her son properly, in the Israelite way ([1], p. 60).

Similarly, Yee argues that "Ruth seems to lose this qualifier [the Moabite] after she finally gives birth to a son (4:13), but it comes at the cost of not being recognized as his mother (4:17)" ([76], p. 130.) The primary reason for this argument is the fact that Obed is taken from Ruth and given to Naomi (Ruth 4:16), and the women rejoice that "a son has been born to Naomi" (Ruth 4:17) ([107], 
p. 130). Effectively, therefore, according to this argument Ruth moves again into the shadows as the "foreign woman" and Ruth is a narrative about Naomi's re-assimilation.

A number of problems exist for sustaining this argument; primarily, as a result of the book's namesake being supposedly too foreign for assimilation, the significance of the relationship between Ruth and Naomi, and indeed between Ruth and Boaz, is misunderstood. Unlike others, who interpret Ruth as "Ruth the Moabite", Boaz recognises Ruth and is willing to go beyond the duties of a Levir in order to intermarry with her. As such Ruth's assimilation began in chapter two when, on a private level, she was interpreted simply as "Ruth" and her Moabite descent was of little significance. Similarly, the relationship between Ruth and Naomi is pivotal not only as an instrument through which Ruth's assimilation is possible, but also because Naomi's re-assimilation is dependent upon Ruth having a child. Smith points out the balance in the narrative in this respect:

Ruth 4:16-17 thus reverses the situation between the two women: Naomi now joins Ruth's family in a manner that completes Ruth's words in 1:16-17. In 4:16-17, Ruth helps to give family to Naomi, just as Naomi accepts Ruth's terms of family in 1:16-17 ([97], p. 258).

In addition, as argued, Naomi's re-assimilation is complex as a result of her return migration. At the beginning of the narrative, Naomi exhibited the typical self-isolating behaviours that characterize return migrants, indeed, attitudes that may be perceived in parts of the post-exilic community (Ezra 9-10; ([52]). However, rather than being a lone return-migrant or part of a group of returnees, Naomi is accompanied by Ruth whose declared intent is assimilation (Ruth 1:16-17). With Ruth's marriage and offspring, Noami's family has been re-established and her original name and identity restored. The formerly embittered Naomi is now central to the celebrations. When read in context, we see that Naomi's being handed Obed is preceded by the statement that Naomi has not been left without a redeemer (Ruth 4:13), and that Ruth "who loves you is better ... than seven sons" (Ruth 4:14) [108]. This is no more the marginalization of a foreigner who has not been assimilated than it is the self-isolation of a distraught returnee. Rather, the two characters are mutually dependent upon each other's assimilation.

\section{Conclusions}

This paper has argued that Ruth's Moabite ethnicity is not "melted" away as an outcome of the process of assimilation. Rather, the narrative's maintenance of tension between the two ethnic identities which Ruth straddles, Moabite and Judean, provides an interesting example of the complexity of assimilation when analysed against the context of modern case studies. Instead of referring to complete or incomplete assimilation, integration, or other such terms, one useful analogy for coming to terms with identifying Ruth's ethnic change is that of "translation". Ruth's Moabite heritage is pivotal for the narrative to operate, but this does not mean that readers should conclude that through intermarriage with Boaz and successful assimilation into Judean society, we should assume that Ruth's Moabite ethnicity has disappeared. Instead, when it comes to Ruth the Moabite, that boundary has shifted and her Moabite ethnicity does not preclude the possibility of assimilation.

However, perhaps the most important conclusion drawn through this comparative study is to note the interdependence between Ruth's and Naomi's assimilation and re-assimilation. Appearing at the 
beginning of the narrative with all the baggage of a return migrant, the prospects for Naomi to assimilate successfully are minimal. Similarly, had Ruth not been given the advantages of family networks and religious networks by virtue of her connection to Naomi, assimilation would have been difficult. Nevertheless, it is the divergence from expected models of behaviour which is perhaps the most intriguing aspect of the research. Initially, Ruth's characterization does not correlate with models of migrant behaviour as a result of her insistence that she remains with Naomi and, as a result, must migrate away from her homeland. Secondly, as the Hebrew pun illustrates, it is strange that Boaz "recognises" Ruth, a self-designated "foreigner". These two exceptions to expected patterns of behaviour within the anthropology and sociology literature consulted enable the narrative in the book of Ruth to retain a sense of charm and beauty. Such attractiveness is far from the ordinary, often traumatic, experiences of modern migrants who choose exile in order flee catastrophes such as the lack of adequate means of economic survival, or famine.

\section{Conflicts of Interest}

The author declares no conflict of interest.

\section{References and Notes}

1. Honig, Bonnie. "Ruth, the Model Emigrée: Mourning and the Symbolic Politics of Immigration." In Ruth and Esther: A Feminist Companion to the Bible. Edited by Athalya Brenner. Sheffield, UK: Sheffield Academic Press, 1999, p. 53.

2. Saxegaard, Kristin M. "'More than seven sons': Ruth as example of the good son." Scandinavian Journal of the Old Testament 15 (2001): 257-75.

3. Matthews, Victor H. "The determination of social identity in the story of Ruth." Biblical Theology Bulletin 36 (2006): 49-54.

4. Lau, Peter H. W. Identity and Ethics in the Book of Ruth: A Social Identity Approach. (Beihefte zur Zeitschrift für die alttestamentliche Wissenschaft; 416). Berlin and Boston: Walter De Gruyter, 2011, p. 92.

5. I have discussed the perils and advantages of this method at length elsewhere (refer to Southwood, Katherine E. Ethnicitiy and the Mixed Marriage Crisis in Ezra 9-10: An Anthropological Approach (Oxford Theological Monographs). Oxford and New York: Oxford University Press, 2012, pp. 1-9.

6. Bruce, Steve, and Steven Yearley. The Sage Dictionary of Sociology. London and Thousand Oaks, CA: SAGE, 2006.

7. Park, Robert E. Race and Culture. Glencoe, Country: Free Press, 1950.

8. Park, Robert E., Ernest W. Burgess, and Roderick D. McKenzie. The City. Chicago: The University of Chicago Press, 1925.

9. Kennedy, Ruby J.R. "Single or triple melting pot? Intermarriage trends in New Haven 1870-1940.” American Journal of Sociology 49 (1944): 331-39.

10. Glazer, Nathan, and Moynihan, Daniel P., eds. Beyond the Melting Pot: The Negroes, Puerto Ricans, Jews, Italians, and Irish of New York City. Cambridge, MA: MIT Press, 1963. 
11. Gordon, Milton M. Assimilation in American Life: The Role of Race, Religion, and National Origins. New York, USA: Oxford University Press, 1964.

12. The negative aspects of such early theories of assimilation are caricatured within the television series Star Trek: The Next Generation. In the episodes, the Borg are a race of Cyborgs that are connected via a hive network to a single brain that controls all of their thoughts and actions. The Borg travel around the universe absorbing other species into their collective through the use of force. Their now classic phrase to future victims is "You will be assimilated. Resistance is futile". (Schafer, Richard T., ed. Encyclopaedia of Race, Ethnicity, and Society. London, Los Angeles, New Delhi, and Singapore: Sage Publications, 2008, vol. 1, p. 104.)

13. Brubaker's definition of assimilation, for instance, as one group becoming similar (in some respect) to another group seems worryingly similar to early conceptualizations of assimilation. (Brubaker, Rogers. Ethnicity without Groups. Cambridge, MA, and London: Harvard University Press, 2004.)

14. Portes, Alejandro, and Min Zhou. "The new second generation: Segmented assimilation and its variants." Annals of the American Academy of Political and Social Science 530 (1993): 74-96.

15. This model usually applies to the second generation.

16. Alba, Richard D., and Victor Nee. Remaking the American Mainstream Assimilation and Contemporary Immigration. Cambridge, MA, and London: Harvard University Press, 2003.

17. Primordialists attribute ethnicity to ties of religion, blood, race, language, region, and custom and consider it to be a fundamental, indefinable aspect of populations (Geertz, Clifford. "The integrative revolution: Primordial sentiments and civil politics in the New States." In Old Societies and New States: The Quest for Modernity in Asia and Africa. Edited by Clifford Geertz. New York, USA: Free Press, 1963, pp. 105-57). In contrast, Instrumentalists define ethnicity as a tool for the pursuit of material interests and power by competing cultural groups who use identity as a social and political resource (Hutchinson, John, and Anthony D. Smith, eds. Ethnicity (Oxford Readers). Oxford and New York: Oxford University Press, 1996, p. 8). Like the differences between early and later assimilation theories, emic approaches which are often taken by natives themselves tend to be primordial, whereas etic approaches are usually instrumental.

18. Barth, Fredrik. Ethnic Groups and Boundaries: The Social Organization of Culture Difference. Oslo, Norway: Universitetsforlaget, 1969.

19. Zolberg, Aristide, and Long L. Woon. "Why is Islam like Spanish: Cultural incorporation in Europe and the United States." Politics and Society 27 (1999): 5-38.

20. Pace Lamont and Molnár who refer to the reinforcement or transcendence of boundaries. (Lamont, Michèle, and Virág Molnár. "The study of boundaries in the social sciences." Annual Review of Sociology 28 (2002): 167-95.)

21. This perspective is noted within Gordon's classic research concerning assimilation where it is argued that each racial and religious group has its own network of cliques, clubs, organizations, and institutions which tend to confine the primary group contact of its members within the ethnic enclave (Gordon, Milton M. Assimilation in American Life.).

22. Cavalcanti, H. B., and Debra Schleef. "The case for secular assimilation? The Latino experience in Richmond, Virginia.” Journal for the Scientific Study of Religion 44 (2005): 473-83. 
23. Guest, Kenneth J. God in Chinatown: Religion and Survival in New York's Evolving Immigrant Community. New York: New York University Press, 2003.

24. Min, Pyong G., and Jung H. Kim. Religions in Asian America: Building Faith Communities. Walnut Creek, CA: Altamira Press, 2003.

25. Ebaugh, Helen R., and Janet S. Chafetz, eds. Religion and the New Immigrants: Continuities and Adaptations in Immigrant Congregations. Walnut Creek, CA: AltaMira Press, 2000.

26. Cha, Peter T. "Ethnic identity formation and participation in immigrant churches: Second generation Korean American experiences." In Korean Americans and Their Religions: Pilgrim and Missionaries from a Different Shore. Edited by Ho Y. Kwon, Kwang C. Kim and R. Stephen Warner. University Park, PA: Pennsylvania State University Press, 2001, pp. 141-56.

27. Kurien, Prema A. "Religion, Ethnicity, and Politics: Hindu and Muslim Indian Immigrants in the United States." Ethnic and Racial Studies 24 (2001): 263-93.

28. Yang, Fenggang. "The Hsi-Nan Chinese Buddhist Temple: Seeking to Americanize.” In Religion and the New Immigrants: Continuities and Adaptations in Immigrant Congregations. Edited by Helen R. Ebaugh and Janet S. Chafetz. Walnut Creek, CA: AltaMira Press, 2000, pp. 67-88.

29. Cao, Nanlai L. "The church as a surrogate family for working class immigrant Chinese youth: An ethnography of segmented assimilation.” Sociology of Religion 66, no. 2 (2005): 183-200.

30. Foner, Nancy, and Richard Alba. "Immigrant religion in the U.S. and western Europe: Bridge or barrier to inclusion?” International Migration Review 42, no. 2 (2008): 360-93.

31. Akresh, Ilana R. "Immigrants' religious participation in the United States." Ethnic and Racial Studies 34, no. 4 (2011): 643-61.

32. Feldman, Shelly. "Community-making in times of displacement: The place of marriage and religious identification among young Muslim men and women." Culture and Religion 13, no. 2 (2012): 265-72.

33. Levitt, Peggy. "Religion as a path to civic engagement." Ethnic and Racial Studies 31, no. 4 (2008): 766-91.

34. Hirschman, Charles. "The role of religion in the origins and adaptation of immigrant groups in the United States.” International Migration Review 38, no. 3 (2004): 1206-33.

35. Warner, R. Stephen. "Religion, boundaries, and bridges." Sociology of Religion 58, no. 3 (1997): 217-38.

36. Social capital can be broadly defined as "the values that people hold and the resources that they can access, which both result in and are the result of collective and socially negotiated ties and relationships" (Edwards, Rosalind, Jane Franklin, and Janet Holland. "Families and social capital: Exploring the issues." Families \& Social Capital ESRC Research Group Working Paper Series, No. 1, South Bank University, London, UK, 2003, p. 2.); Cf. Franklin, Jane. "Social capital: Between harmony and dissonance." Families \& Social Capital ESRC Research Group Working Paper 18, London South Bank University, London, UK, 2007; Halpern, David, Social Capital. London, UK: Polity Press, 2005; Field, John. Social Capital (Key Ideas Series). London, UK: Routledge, 2003). Social capital, therefore, results in collective economic benefits achieved as a result of preferential treatment and cooperation between individuals and groups. As such it illustrates the financial benefits of social networks. Putnam argues that social capital can have a bonding or a bridging role; bonding refers to values assigned to social networks between 
homogeneous groups, for example between a group of immigrants, and bridging to social networks between socially heterogeneous groups, for example, immigrants and members of a host society. (Putnam, Robert D. Bowling Alone: The Collapse and Revival of American Community. New York: Simon \& Schuster, 2000.)

37. Greely, Andrew. "Coleman revisited: Religious structures as a source of social capital." The American Behavioral Scientist 40, no. 5 (1997): 587-94.

38. Allen, Ryan. "The bonding and bridging roles of religious institutions for refugees in a non-gateway context." Ethnic and Racial Studies 33, no. 6 (2010): 1049-68.

39. Kasinitz, Philip, John H. Mollenkopf, Mary C. Waters, and Jennifer Holdaway. Inheriting the City: The Children of Immigrants Come of Age. New York: Russell Sage Foundation, 2008.

40. Sutton, Constance. "Celebrating Ourselves: The Family Rituals of African-Caribbean Transnational Families.” Global Networks 4, no. 3 (2004): 243-57.

41. Levitt, Peggy. The Transnational Villagers. Berkeley, CA: University Of California Press, 2001.

42. Edwards, Rosalind, Jane Franklin, and Janet Holland. "Families and Social Capital: Exploring the Issues." Families \& Social Capital ESRC Research Group Working Paper Series, No. 1, South Bank University, London, 2003.

43. Morrow, Virginia. "Conceptualising social capital in relation to the wellbeing of children and young people: A critical review.” Sociological Review 47, no. 4 (1999): 744-65.

44. Putnam, Robert D. Bowling Alone: The Collapse and Revival of American Community. New York: Simon \& Schuster, 2000.

45. Reynolds, Tracey. "Friendship networks, social capital and ethnic identity: Researching the perspectives of Caribbean young people in Britain.” Journal of Youth Studies 10, no. 4 (2007): 383-98.

46. Reynolds, Tracey. "Family and community networks in the (re)making of ethnic identity of Caribbean young people in Britain." Community, Work and Family 9, no. 3 (2006): 273-90.

47. Reynolds, Tracey. "Caribbean young people, family relationships and social capital; special issue: social capital, migration and transnational families." Journal of Ethnic and Racial Studies 29, no. 6 (2006): 1087-103.

48. Goulbourne, Harry, and John Solomos. "Families, Ethnicity and Social Capital." Social Policy and Society 2, no. 4 (2003): 329-38.

49. Shaw, Alison. Kinship and Continuity: Pakistani Families in Britain. Amsterdam: Harwood Academic, 2000.

50. Bacon's study shows how even bonding social capital can be fragmented through migrant family networks who "repeatedly stress their distinction from 'other Indians"” (Bacon, Jean. Life Lines: Community, Family, and Assimilation among Asian Indian Immigrants. Oxford and New York: Oxford University Press, 1996, p. 4).

51. Southwood, Katherine E. Ethnicitiy and the Mixed Marriage Crisis in Ezra 9-10: An Anthropological Approach (Oxford Theological Monographs). Oxford and New York: Oxford University Press, 2012, pp. 41-56.

52. King, Russell, and Anastasia Christou. "Cultural Geographies of Counter-Diasporic Migration: The Second Generation Returns 'Home'.” Sussex Centre for Migration Research Working Paper 45, University of Sussex, Brighton, UK, 2008. 
53. Byron, Margaret. "Return migration to the Eastern Caribbean: Comparative experiences and policy implications." Social and Economic Studies 49, no. 9 (2000):155-89.

54. Ghosh Bimal, ed. Return Migration: Journey of Hope or Despair? Geneva: International Organization for Migration and the United Nations, 2000.

55. King, Russell. "Generalizations from the history of return migration." In Return Migration: Journey of Hope or Despair. Edited by Bimal Ghosh. Geneva: International Organization for Migration and the United Nations, 2000, pp. 7-55.

56. King, Russell, ed. Return Migration and Regional Economic Problems. London: Croom Helm, 1986.

57. Gmelch, George. Double Passage: The Lives of Caribbean Migrants Abroad and Back Home. Ann Arbor: The University of Michigan Press, 1992.

58. Romanticised notions of a homeland often develop among immigrants. Such conceptualizations of the homeland are characterized by a deep-rooted identification and emotional attachment to the place of imagined origins. Such notions of the homeland reflect migrants' own interpretations of their roots, their celebration of cultural heritage, and importance of "knowing where you come from" for the construction of self-identity (Basu, Paul. Highland Homecomings: Genealogy and Heritage Tourism in the Scottish Diaspora. London: Routledge, 2007).

59. Reynolds, Tracey. "Transnational family relationships, social networks and return migration." Ethnic and Racial Studies 33, no. 5 (2010): 797-815.

60. Cf. Southwood, Katherine E. “'And they could not understand Jewish Speech': Ethnicity, language, and Nehemiah's intermarriage crisis.” Journal of Theological Studies 62, no. 1 (2011): $1-19$.

61. Tiemoko, Richmond. "Migration, Return and Socio-Economic Change in West Africa: The Role of Family.” Sussex Migration Working Paper 15, Sussex Centre for Migration Research, Sussex, England, 2003, pp. 1-17.

62. Reynolds, Tracey. "Ties That Bind: Families, Social Capital and Caribbean Second-Generation Return Migration.” Sussex Migration Working Paper 46, Sussex Centre for Migration Research, Sussex:England, 2008, pp. 1-29.

63. Olwig, Karen F. Caribbean Journeys: An Ethnography of Migration and Home in Three Family Networks. Durham: Duke University Press, 2007.

64. Foner, Nancy. Islands in the City: West Indian Migration to New York. Berkeley: University of California Press, 2001.

65. Potter, Robert B. "The socio-demographic characteristics of second-generation return migrants to St Lucia and Barbados.” In The Experience of Return Migration: Caribbean Perspectives. Edited by Robert B. Potter, Dennis Conway and Joan A. Phillips. Aldershot: Ashgate, 2005.

66. The "Myth of Return" is the idea, recognized widely within the research relating to return migration, that although many migrants dream of returning to their homeland, few actually return. As such, the idea of returning remains a myth (Cf. Southwood, Katherine E, Ethnicity and the Mixed Marriage Crisis in Ezra 9-10, pp. 48-49).

67. Boer, Roland. Marxist Criticism of the Bible. London: T \& T Clark, 2003.

68. Brenner, Athalya, ed. Ruth and Esther. Sheffield: Sheffield Academic Press, 1999, p. 53.

69. Oznik, Cynthia. "Ruth.” In Reading Ruth: Contemporary Women Reclaim a Sacred Story. Edited by Judith A. Kates and Gail T. Reimer. New York and Canada: Ballatine, 1994, pp. 211-32. 
70. Matthews, Victor H. Judges and Ruth. NCBC. Cambridge: Cambridge University Press, 2004, p. 222; cf. Ruth 1:16-17. The idea of Ruth 1:16-17 as a verbal contractual agreement arises from Sasson who argues in his folklorist commentary that the concept of "love" אהב that is applicable here, as in the slave's love for his master (cf. Exod. 21.2-6[5]), is a legal rather than an emotional concept. As such, it indicates intent as well as consent (Sasson, Jack M. Ruth: A New Translation with a Philological Commentary and a Formalist-Folklorist Interpretation. Sheffield: Journal for the Study of Old Testament Press, 1989, p. 124). The "love" אהב which is used to describe the relationship of Ruth to Naomi (Ruth 4:15) has connotations of the relationship between an inferior and superior, a vassal and his lord, a slave and his master (Ackerman, Susan. "The Personal Is Political: Covenantal and Affectionate Love in the Hebrew Bible." Vetus Testamentum 52 (2002): 437-58). As such, Brenner argues that Ruth would have had little choice about accompanying Naomi in her return and about acquiescing to what Halton labels Naomi's "indecent proposal" (Brenner, Athalya. "Ruth as a Foreign Worker and the Politics of Exogamy." In Ruth and Esther. Edited by Athalya Brenner. Sheffield, UK: Sheffield Academic Press, 1999, pp. 158-62; Halton, Charles. "An Indecent Proposal: The Theological Core of the Book of Ruth.” Scandinavian Journal of the Old Testament 26, no. 1 (2012): 30-43).

71. It is unlikely that Ruth 1:16-17 represents religious conversion (refer to the discussion below).

72. Brenner, Athalya. "Ruth as a Foreign Worker and the Politics of Exogamy." In Ruth and Esther. Edited by Athalya Brenner. Sheffield, UK: Sheffield Academic Press, 1999, pp. 161-62. Italics in original.

73. Ruth $1: 22 ; 2: 2,21 ; 4: 5,10$. (Refer below for further discussion of this epithet).

74. The preposition is chosen carefully to reflect the positions taken within such ethnocentric theories of assimilation. Rather than assimilating "with" host societies, early theories of assimilation expected migrants to assimilate "to" the American mainstream.

75. Gen. 19:37; Num. 22-24; 25:1-3; Deut. 23:3-4. The notion of a "good" Moabite would one be perceived as an oxymoron. Moab was the product of incest, when Lot's daughters got their father drunk and had sex with him, seeing no other way to have children (Gen. 19:30-38). Later, Moabite women solicited Israelite men into sexual relations as well as heterodox worship (Num. 25:1-3). Both stories would raise eyebrows about Ruth. Moreover, Moab was often an enemy of Israel, and Deuteronomy prohibits Moabites from membership in the "assembly" (Deut 23:3).

76. Yee, Gale A. "'She Stood in Tears amid the Alien Corn': Ruth, the Perpetual Foreigner and Model Minority." In They Were All Together in One Place: Toward Minority Biblical Criticism. Edited by Randall C. Bailey, Tat-siong B. Liew and Fernando F. Segovia. Atlanta: Society of Biblical Literature, 2009, p. 128.

77. Ostriker, Alice. "The Book of Ruth and the Love of the Land." Biblical Interpretation 10, no. 4 (2002): 352-53.

78. For a discussion of the formulaic ${ }^{\text {7w }}$ refer to Southwood, Katherine S., Ethnicity and the Mixed Marriage Crisis in Ezra 9-10, pp. 163-75.

79. A derogatory caricature in the popular imagination of older theories of assimilation (refer to note 12).

80. Merton, Robert K. "Intermarriage and social structure: Fact and theory." Psychiatry 4, no. 3 (1941): 361-74. 
81. Hypergamy is a term usually applied to young women who marry into a higher status or caste than themselves. It should be noted that Merton's model of hypergamy has been questioned as a result this gender bias (there is no reason why men should not marry up), and the use of other subjective indicators such as beauty (Liang, Zai, and Naomi Ito. "Intermarriage of Asian Americans in the New York City Region: Contemporary Patterns and Future Prospects." International Migration Review 33, no. 4 (1999): 876-900.)

82. Schoen, Robert, and John Wooldredge. "Marriage Choice in North California and Virginia, 1969-71 and 1979-81." Journal of Marriage and the Family 51 (1989): 465-81.

83. Glover illustrates the methodological problems associated with measuring Ruth's ethnic change. Unilateral Situationalists would "suggest that Ruth becomes an Israelite upon her pledge of allegiance to Naomi. Ruth becomes an Israelite at Ruth 1.16". In contrast, Sympathetic Constructivists "may argue the welcome Ruth receives from the Bethlehem assembly meets the necessary criteria for ethnic membership. Ruth becomes an Israelite at Ruth 4.11". However, Hard Primordialists "will resist any of the above: ethnicity is immutable; neither speeches of allegiance nor community welcomes can do anything to erase the Moabite gene. Ruth never becomes an Israelite" (Glover, Neil. "Your People, My People: An Exploration of Ethnicity in Ruth." Journal of the Society of Old Testament Studies 33, no. 3 (2009): 295). While this approach to the topic underlines the complexity of ethnicity and how careful biblical scholars must be when taking such a concept to the Hebrew Bible, it fails to acknowledge that primordialism, and certainly hard primordialism are a minority view within the field. Indeed, some would argue that primordialism and situationalsim equate roughly to emic and etic perspectives on ethnicity; while indigenous communities are often primordial in their approaches, fieldwork researchers usually take a more instrumental approach to the topic. As such, Glover may have developed this approach more thoroughly.

84. Jackson, Melissa A. Comedy and Feminist Interpretation of the Hebrew Bible: A Subversive collaboration. Oxford and New York: Oxford University Press, 2012. Jackson argues that rather than being merely a narrative concerning matters such as ethnicity, assimilation, the homeland, marriage and so on, Jackson's interpretation of the book's insistence on the Moabite identity of Ruth is designed for comic hyperbole. Whether comic or not, the repetition certainly clarifies the importance of Ruth's ethnic otherness.

85. Glover, Neil. "Your People, My People: An Exploration of Ethnicity in Ruth." Journal of the Society of Old Testament Studies 33, no. 3 (2009): 293-313.

86. Cf. Bennett, Harold V. Injustice Made Legal: Deuteronomic Law and the Plight of Widows, Strangers, and Orphans in Ancient Israel. Grand Rapids: Eerdmans, 2002.

87. The pun between the verb "recognize" נכר hiphil infinitive and the noun "foreign" נכר is ironic, a foreigner is precisely the type of person who goes unrecognized (Linafelt, Tod, David Cotter, Jerome T. Walsh, and Chris Franke. "Ruth.” In Berit Olam: Studies in Hebrew Narrative and Poetry. Collegeville, MN: Liturgical Press, 1999, p. 36). This point is exemplified in Brenner's argument concerning foreign female workers (Brenner, Athalya, "Ruth as a Foreign Worker").

88. An exception to this is the attitude towards strangers that is expressed within Solomon's prayer 1 Kings 8:41-43// 2 Chr. 6:32-33. 
89. Lau's discussion of Ruth's possible dating provides a list of seven reasons why Ruth is usually understood as a post-exilic composition (Lau, Peter H.W. Identity and Ethics in the Book of Ruth: A Social Identity Approach. Berlin and Boston: Walter De Gruyter, 2011, p. 44):

- The alleged Aramaisms and late biblical Hebrew ... forms.

- The legal customs reflect a time when the customs were obsolete or required explanation....

- The similarity between the genealogy (4:18-22) and the "priestly" genealogies of the Pentateuch and Chronicles (e.g., 1 Chr. 2:3-15).

- The favourable portrayal of the Moabitess Ruth, which is thought to balance the ethno-centrism of post-exilic texts such as Ezra and Nehemiah.

- The allusion to a post-exilic "Deuteronomic" edition of the book of Judges (1:1).

- The canonical placement of Ruth among the Writings, based on the assumption that these were collected after the prophetic collection had been completed.

- The suitability of the theme of outward homeward journey with the experience of exile.

90. Clines, David J.A., ed. The Dictionary of Classical Hebrew. Sheffield: Sheffield Academic Press, 2001, vol. 5, pp. 692-94.

91. Ostriker, Alice S. For the Love of God: The Bible as an Open Book. New Brunswick, NJ: Rutgers University Press, 2007, p. 47.

92. Lau, Peter H.W. Identity and Ethics in the Book of Ruth. Lau, who argues that narrative inherently contains ethical principles, utilizes social identity theory during his discussion which claims that the principle character trait of Ruth and of Boaz is חסת. However, according to Lau both characters' identity are formed by the tension between personal and social identity.

93. It has long been recognised that migrant behaviour often accentuates the practices, especially the religious practices of the homeland. This perspective has been applied to exile in the Old Testament (Smith-Christopher, Daniel L. A Biblical Theology of Exile (Overtures to Biblical Theology). Minneapolis: Fortress Press, 2002; Smith-Christopher, Daniel L. The Religion of the Landless: The Social Context of the Babylonian Exile. Bloomington, Indiana: Meyer-Stone Books, 1989). Upon return, the type of Yahwism practiced by Naomi and her family in exile may have differed slightly from that of those who never left (Southwood, Katherine E., Ethnicity and the Mixed Marriage Crisis in Ezra 9-10, pp. 191-213).

94. Although a perspective rejected by scholars, Ruth's pledge has been understood by much of Jewish tradition as an expression of conversion (Campbell, Edward F. Ruth: A New Translation with Introduction, Notes, and Commentary (Anchor Bible Commentaries, 7). New Haven: Yale University Press, p. 80; Nielsen, Kirsten. Ruth: A Commentary (Old Testament Library). London: SCM, 1997, p. 49; cf. Targum Ruth 1:16). As such, Ruth is sometimes caricatured as a protest against the approach that Ezra and Nehemiah take concerning foreign women. For example, Amit claims that the references to Ruth as a Moabite evoke an "implicit polemic" against the "Ezra-Nehemiah attitude toward foreign women" (Amit, Yaria. Hidden Polemics in Biblical Narrative (Biblical Interpretation, 25). Leiden, Boston, Cologne: Brill, 2000, pp. 84-87). Perhaps a better juxtaposition is between the simplistic exclusion of foreigners and the responsibility towards foreigners who should be treated fairly (Ex. 12:49; 20:10; 22:11; Lev. 19:33; Deut. 10:14-19) and for whom some of the harvest is left (Lev. 19:9; 23:22). Thus, Matthew asks "is there some post-exilic issue being raised here beyond the endogamy 
requirement that has to do with a larger legal issue of what responsibility the Israelite has for the safety of foreigners, as well as their acceptance into the community through legal practice and marriage?" (Matthews, Victor H, “The Determination of Social Identity," p. 52).

95. Sasson, Jack M. Ruth: A New Translation with a Philological Commentary and a Formalist-Folklorist Interpretation. Sheffield: Journal for the Study of Old Testament Press, 1989, p. 124.

96. Frymer-Kensky, Tikva. Reading the Women of the Bible: A New Interpretation of Their Stories. New York: Schocken, 2002, p. 241.

97. Smith, Mark S. "'Your People Shall Be My People': Family and Covenant in Ruth 1:16-17." Catholic Biblical Quarterly 69, no. 2 (2007): 242-58.

98. While Ruth's gleaning from Boaz's field may suggest collective support of the poor (Ruth 2; Lev. 19:9; 23:22) is it also possible that commands to protect the foreigner and sojourner may provide a suitable means of contextualizing the narrative (Ex. 12:49; 20:10; 22:21; Lev. 19:33; Deut. 10:14-19; cf. Ostriker, Alice S., For the Love of God).

99. On one level, Ruth is simply asking for refuge by reapplying Boaz's previous blessing concerning finding refuge under Yaheh's wings (Ruth 2:12). However, few have failed to note the suggestive uncovering of feet (Ruth 3:7). Perhaps, as Sasson suggested, "the storyteller meant to be ambiguous and hence provocative" (Sasson, Jack M., Ruth: A New Translation, p. 71). Van Wolde suggests that what Ruth uncovers is herself (Van Wolde, Ellen. "Intertextuality: Ruth in Dialogue with Tamar." In A Feminist Companion to Reading the Bible: Approaches, Methods and Strategies. Edited by Athalya Brenner and Carole Fontaine. Sheffield: Sheffield Academic Press, 1997, p. 435). Halton describes Naomi's interference as sexual entrapment (Halton, Charles, "An Indecent Proposal"). Furthermore, it should be noted in relation to this incident that many commentators have acknowledged the theme of fertility that runs throughout the narrative. As Ostriker comments, "While it begins with a famine precipitating the plot, its major scenes occur during a time of plentiful harvest, and the connection between natural harvest and human sexuality and fruitfulness is made clear" (Ostriker, Alice S., For the Love of God, p. 39).

100. In his acting as a redeemer and husband to Ruth, Boaz actually goes beyond the requirements of the Levir; there is a nearer kinsman (Ruth 4:1-4) and, more importantly, Boaz is not identified as the brother of a dead husband. The narrator does however mention this was a practice of "former times" (Ruth 4:7). As Saxegaard comments "In Ruth ...it seems that the law is given a wider, more liberal interpretation. The terms "relative" and "kinsman" appear quite frequently $(2: 1,20$; $3: 2,9,12 ; 4: 1,3,6)$. Boaz is presented as a "relative" (2:1) and immediately seen as a possible kinsman by Naomi. When things get serious, however, Naomi does not relate to any kinsman-law, but arranges things in her own way by telling Ruth to go to Boaz at night (3:1ff) (Saxegaard, Kristin M., "More than Seven sons"). It should also be acknowledged that some have compared Naomi's manipulation of Ruth and Boaz to Tamar and Judah (Halton, Charles, “An Indecent Proposal,” p. 35; Matthews, Victor, Judges and Ruth, p. 234).

101. Brenner goes so far as to state that "integration in the host community can only be achieved by marriage" (Brenner, Athalya, "Ruth as a Foreign Worker," p. 160). This is rather problematic initially because of the lack of clarity regarding the term integration (in light of the discussions introducing this paper, Brenner may mean assimilation at this point), and secondly, because the 
literature from social anthropology surveyed in this essay concerning assimilation suggests that although marriage is a long-standing indicator of assimilation, other means of assimilation do, nevertheless, exist.

102. However, it should be noted that the verb's repetition plays on the ambiguity of its meaning turn/return. As Jackson notes, "Naomi and her daughters-in-law discuss their future and who will turn/return" (Jackson, Melissa A., Comedy and feminist interpretation, p. 186).

103. As noted formerly, return migration sometimes results in alienation and former idealised perceptions of the homeland being undone (Southwood, Katherine E., Ethnicity and the Mixed Marriage Crisis in Ezra 9-10, pp. 41-55; King, Russell, and Anastasia Christou, Cultural Geographies of Counter-Diasporic Migration; Byron, Margaret, "Return migration to the Eastern Caribbean,”; Gmelch, George, Double Passage.). Accents were also highlighted as increasing the sense of being an "outsider" (Reynolds, Tracey, "Transnational Family Relationships,” p. 807). Interestingly, Lim argues that Ruth's speech marks her out as a foreigner: Ruth's Hebrew is very good, though uneven. She is made to express one of the most memorable lines of filial piety in the Hebrew Bible. Yet, counterbalancing this speech, her understanding lapses in reporting what Boaz has said. The grammatical solecism of 2:21 underscores her foreignness.... It seems that the author intended to emphasize her alien status, her Otherness, by reminding the reader that she was "Ruth the Moabitess" and to underscore this by making her speak with some inflections of the Hebrew language. (Lim, Timothy H. "How Good Was Ruth's Hebrew? Ethnic and Linguistic Otherness in the Book of Ruth." In The "Other" in Second Temple Judaism. Essays in Honor of John J. Collins. Edited by Daniel C. Harlow, Karina Martin Hogan, Matthew Goff, and Joel S. Kaminsky. Grand Rapids, Michigan and Cambridge, U.K.: Eerdmans, 2011, p. 114). However, the text itself and the instances of speech within the text are so minor that it is difficult to firmly establish a case either way. Indeed, Lim mentions only one error in Ruth's speech, confusion between male and female servants, which could be the author's intention to make her sound foreign, but could also be explained otherwise (e.g., scribal error).

104. While Naomi's position as a return migrant is a complication in terms of assimilation, it nevertheless endows her with a degree of social capital. Naomi has local knowledge, is recognized, and has ties. However it is not uncommon for some return migrants to fail to re-assimilate. Ironically, part of the reason that Naomi is finally able to re-assimilate successfully is her renewed family network through Ruth (the foreigner who at first glance would be more unlikely to assimilate than Naomi), who bares Obed (Ruth 4:14-17).

105. This uses the qere reading. The verb is a pual participal from $\bigvee_{y}$ 'י Refer to BHQ 18 (Megilloth), p. 5.

106. Furthermore, like Abraham, Ruth is blessed and becomes a "great nation" (Gen. 12:2; Ruth $4: 18-22)$.

107. Irwin suggests the possibility of a tiqune sopherim in Ruth 3:3, arguing that "if the verbs in question are taken as first common singular forms, the passage reads as follows 'Dress, anoint yourself and put on your cloak. I will go down to the threshing floor... I will lie down."' By making Ruth and Naomi present at the threshing floor scene, Irwin suggests that a later scribe committed to the letter and spirit of Deut. 23.4, these changes remove the rather unpalatable 
prospect of having a Moabite widow incorporated into the Israelite community and the line of Israel's greatest king (Irwin, Brian, P. "Removing Ruth: Tiqqune Sopherim in Ruth 3.3-4?" Journal of the Society of Old Testament Studies 32, no. 3 (2008): 331-38 (pp. 336-37). Such a reading is compatible with the observation that the infant Obed is placed on Naomi's lap. However, without further textual evidence, this suggestion cannot be fully substantiated.

108. This is an interesting insight into women's groups within the Hebrew Bible. As Ostriker comments "Ruth is the only book of the Bible that gives us a hint of a women's community and social life existing alongside yet distinct from male society" (Ostriker, Alice S., For the Love of God, p. 41). It is the women who greet Naomi and at the tale's close congratulate her, offer blessing, and even name the new-born child. Similarly, Meyers who examines recent ethnographic research concerning "women's networks", argues that the narrative depicts the behaviour of women in informal groups. Women join together to greet Ruth and Naomi and perhaps to help them establish themselves in Naomi's marital community (Meyers, Carol. “'Women of the Neighbourhood' (Ruth 4:17): Informal Female Networks in Ancient Israel." In Ruth and Esther. Edited by Athalya Brenner. Sheffield: Sheffield Academic Press, 1999, p. 121). In light of these observations, an interesting avenue for further research concerning factors which have an impact upon assimilation may be the existence of such networks.

(C) 2014 by the author; licensee MDPI, Basel, Switzerland. This article is an open access article distributed under the terms and conditions of the Creative Commons Attribution license (http://creativecommons.org/licenses/by/3.0/). 